\title{
PROFILE OF HIGH TOUCH IN THE APPLICATION LEARNING PROCESS
}

\author{
Ali Mashari \\ STKIP AL Islam Tunas Bangsa Bandar Lampung
}

\begin{abstract}
This research generally aims to get brief description of application high touch in learning process. This research is conducted by descriptive quantitative method. The population is all teachers and students at senior high school. Samples are taken by using stratified cluster random sampling technique. The percentage, correlation and $\mathrm{t}$ test. The results of this research reveal that application high touch in learning process less and teachers' opinion about high touch implementation as implication of teachers' understanding toward learning process differ significantly with students' opinion. In general, teachers' opinion score is higher compared with student's opinion score
\end{abstract}

Keywords: high touch, learning process, students

\section{PENDAHULUAN}

Proses pembelajaran, pada dasarnya tidak dapat dilepaskan dari pemahaman pendidik tentang peserta didiknya. Hal ini dikarenakan pandangan pendidik terhadap peserta didik tersebut akan mendasari pola pikir dan perlakuan yang diberikan kepada peserta didiknya. Pembelajaran merupakan suatu proses yang kompleks, sebab dalam setiap pembelajaran peserta didik tidak sekedar menyerap informasi dari pendidik, tetapi melibatkan potensinya dalam melaksanakan berbagai kegiatan maupun tindakan yang harus dilakukan, terutama bila diinginkan hasil belajar yang baik, yaitu hasil belajar yang bermakna, komprehensif, dan berguna dalam kehidupan peserta didik.

Konsep pembelajaran menurut Covey (1997) adalah suatu proses di mana lingkungan secara disengaja dikelola untuk memungkinkannya turut serta dalam tingkah laku tertentu dalam kaitannya dengan pencapaian tujuan pembelajaran. Proses pembelajaran dalam upaya pencapaian tujuan tersebut, sangat dipengaruhi tipe/gaya guru dalam melaksanakan proses pembelajaran (Ballantine, 1983:189). 
Guru memiliki posisi dan peran yang strategis dalam meningkatan kualitas proses pembelajaran di kelas. Peran tersebut antara lain dapat dilakukan melalui pengoptimalan segenap kompetensi pribadi dalam melakukan perubahan untuk penyelenggaraan proses pembelajaran yang lebih baik ( G Michael (1993:118). Kepribadian guru yang baik, tercermin dari gayanya melaksanakan proses pembelajaran yang efektif. Guru yang efektif antara lain ditandai dengan lima pokok karakter perilaku yaitu kejelasan dalam memberikan materi pelajaran, menguasai teknik penyampaian materi, berorientasi kepada perkembangan siswa, menekankan kepada proses pembelajaran (keaktifan siswa), dan berorientasi pada kesuksesan siswa

Proses pembelajaran harus mampu mengembangkan segenap segenap potensi peserta didik. Pengembangan itu mencakup keseluruhan hakekat dan dimensi kemanusiaan serta pancadaya yang dimiliki peserta didik melalui teraplikasikannya kewibawaan (hightouch) dalam setiap proses pembelajaran yang diselenggarakannya. pendidik yang kurang memahami peserta didik akan menyebabkan terjadi praktik-praktik pembelajaran yang kurang memberikan kemungkinan terhadap pengembangan potensi peserta didik. Akibatnya potensi peserta didik akan terabaikan, tersiasiakan dan bahkan mungkin terdholimi. Sebab, kewibawaan pendidik yang meliputi unsur pengakuan, kasih sayang dan kelembutan, pengarahan, penguatan dan tindakan tegas yang mendidik serta keteladanan tidak teraplikasikan dalam proses pembelajaran.

Di sekolah, disinyalir masih banyak pendidik yang belum memahami dan mengetahui hakekat peserta didik secara baik dan benar. Akibatnya dalam proses pembelajaran, belum sepenuhnya terlihat adanya internalisasi nilai-nilai yang terkandung dalam materi pelajaran dalam usaha pengembangan potensi yang dimiliki peserta didik yang mencakup berbagai dimensi kemanusiaan dan pancadaya mereka. Kenyataan ini dapat terlihat pada adanya perlakuan-perlakuan yang kurang mendidik dari pendidik terhadap peserta didik, antara lain, membentak di depan umum, melabeli 
dengan gelar yang buruk, seperti $\mathrm{Si}$ Bodoh, Si Tolol dan sebagainya. Hasil penelitian yang dilakukan Robinson (1986) menyimpulkan bahwa pemberian label kepada peserta didik di sekolah memiliki pengaruh yang kuat terhadap keberhasilan atau kegagalan peserta didik. Label yang buruk akan menyebabkan peserta didik identik dengan label yang diberikan. Sedangkan label yang baik akan meningkatkan harapan yang besar bagi peserta didik untuk meraih keberhasilan.

Tindakan-tindakan pendidik yang kurang memahami hakekat peserta didik tersebut pada akhirnya, mengakibatkan peserta didik merasa kurang dihargai. Hal itu, menimbulkan kondisi yang kurang kondusif dalam belajar dan kurang memberikan kemungkinan terhadap terkembangkannya seluruh potensi yang dimiliki oleh peserta didik, akan tetapi, malahan akan cenderung mematikannya.

Pemahaman guru tentang peserta didik yang benar akan tercermin dalam pengembangan segenap potensi siswa peserta didik. Pengembangan itu mencakup keseluruhan dimensi kemanusiaan siswa melalui teraplikasikannya kewibawaan di (Pokja Pengembangan Peta Keilmuan Pendidikan, 2005).

Sebaliknya, guru yang kurang memahami peserta didik akan menyebabkan terjadi praktek-praktek pembelajaran yang kurang memberikan kemungkinan terhadap pengembangan potensi peserta didik. Akibatnya peserta didik akan terabaikan, tersiasiakan dan bahkan mungkin terdholimi. Sebab, kewibawaan yang meliputi unsur pengakuan, kasih sayang dan kelembutan, pengarahan, penguatan dan tindakan tegas yang mendidik serta keteladanan, tidak teraplikasikan dalam proses pembelajaran (Prayitno., dkk. 2005).

Pendidik dituntut tanggung jawabnya untuk melaksanakan proses pembelajaran secara profesional, yaitu praktik pendidikan yang didasarkan pada kaidah-kaidah keilmuan pendidikan. Esensi permasalahan peningkatan profesionalisme pendidikan menurut Winarno (2005) adalah masalah akuntabilitas pendidik. Ia melontarkan sinisme bahwa praktik pendidikan yang dilaksanakan oleh pendidik di sekolah tidak didasari oleh 
ilmu pendidikan atau "pentip" (pendidikan-tanpa-ilmu pendidikan).

Pendidik secara leluasa "mementip" peserta didik dalam proses pembelajaran tanpa dasar ilmu pendidikan yang kuat atau bahkan tidak dimiliki sama sekali. Praktik pendidikan yang demikian ini, tentu saja tidak dapat mengembangkan potensi yang dimiliki peserta didik, dan mungkin bisa merapuhkan dan bahkan mematikannya. "Pentip" dapat menimbulkan berbagai permasalahan belajar dan permasalahan umum lainnya (Ida Umami, 2004). Kenyataan ini diperkuat oleh hasil penelitian Prayitno., dkk (2005) yang mengungkapkan banyaknya permasalahan yang dialami peserta didik terkait dengan proses pembelajaran yang kurang efektif disebabkan pembelajaran yang kurang mengindahkan kewibawaan tetapi terfokus pada aspek kewiyataana.

Kelas yang efektif ditunjang iklim sekolah yang memfasilitasi tugas pendidik menjadikan semua ruang kelas sebagai effective classrooms. Mohd Ansyar (2005:1) juga mengemukakan bahwa diperlukan adanya perbaikan yang mendasar pada proses pembelajaran di dalam kelas (classroom change) sesuai konsep pembelajaran yang baik. Sehingga banyak kelas harus berfungsi sebagai basis pembelajaran dari pada sebagai arena pengajaran.

Kenyataan bahwa pendidik sering menampilkan gaya yang kurang disenangi peserta didik seperti pemarah dan cepat emosional, cerewet dan pilih kasih, bertentangan dengan kebutuhan peserta didik yang sangat menginginkan penampilan pendidik yang tidak pemarah/emosional, pendidik yang baik, ramah, pintar dan penuh perhatian. Hubungan yang terjadi antara pendidik dengan peserta didik dalam proses pembelajaran hendaknya terhindar dari gaya/penampilan pendidik yang cenderung memposisikan peserta didik pada kedudukan yang inferior, pasif, lebih menunjukkan pada permusuhan dan pelecehan terhadap kemanusiaan dan potensi yang dimiliki peserta didik. Kondisi negatif dalam hubungan pendidik dengan peserta didik bersifat kontraproduktif terhadap motivasi untuk mendorong peserta didik belajar dengan lebih giat dan lebih berhasil dalam mencapai tujuan pembelajaran. 
Sebaliknya pembelajaran yang cenderung kurang mengaplikasikan high touch membuat peserta didik kurang bergairah mengikuti pelajaran dalam perwujudan sikap acuh tak acuh terhadap pendidik, tidak mau memperhatikan pelajaran yang disampaikan pendidik, mengantuk, melamun, atau bahkan sengaja menciptakan suasana yang kurang kondusif dalam proses pembelajaran seperti sengaja mengganggu teman, mengejek pendidik, keluar pada waktu pendidik mengajar dan sebagainya. Kondisi sebagaimana digambarkan ini tentu saja tidak akan mendukung terciptanya situasi bagi terwujudnya lingkungan belajar yang kondusif untuk mengoptimalkan pembelajaran, sehingga tujuan yang telah ditetapkan akan sulit untuk dicapai. Hal ini semua tidak serasi dengan penerapan ilmu pendidikan yang konter produktif terhadap upaya untuk mengoptimalkan pembelajaran dan meminimalkan pengajaran.

\section{Berdasarkan}

fenomena sebagaimana dipaparkan di atas, dirasakan mendesak adanya usaha yang mengarah kepada perbaikan penerapan kewibawaan dalam proses pembelajaran dalam upaya pencapaian tujuan pendidikan akan dapat diwujudkan seirama dengan segenap potensi yang dimiliki peserta didik yang dikenal baik oleh pendidik.

Berdasarkan paparan latar belakang masalah di atas, maka masalah penelitian adalah bagaimana profil penerapan kewibawaan dalam proses pembelajaran. Secara umum penelitian ini bertujuan untuk memperoleh gambaran berkenaan dengan penerapam kewibawaan dalam proses pembelajaran melalui penerapan high touch menurut pendidik dan peserta didik serta perbedaannya antar variabel, yaitu variabel kelas, sekolah dan jenis kelamin, sumbangan pemahaman pendidik tentang peserta didik terhadap aplikasi penerapan high touch dalam proses pembelajaran dan profil aplikasi pemahaman pendidik tentang peserta didik dalam proses pembelajaran melalui penerapan high touch.

Hasil penelitian ini diharapkan bermanfaat bagi kepala sekolah dalam meningkatkan kualitas pendidik dalam proses pembelajaran, terutama berkenaan dengan pemahaman pendidik/pendidik tentang hakekat 
peserta didik, sehingga proses pembelajaran tersebut menumbuhkan suasana yang memungkinkan peserta didik untuk dapat mengembangkan segenap dimensi kemanusiaan dan pancadaya sesuai dengan harkat dan martabat kemanusiaannya.

Hasil penelitian juga diharapkan bermanfaat bagi pendidik dalam meningkatkan wawasan, pengetahuan, keterampilan, dan sikap berkenaan dengan pemahamannya tentang hakekat peserta didik dan aplikasinya dalam proses pembelajaran melalui penerapan high touch, sehingga setiap proses pembelajaran tersebut diwarnai dengan penghargaan yang tinggi terhadap peserta didik sesuai dengan hakekat kemanusiaannya.

\section{METODE}

$$
\begin{aligned}
& \text { Penelitian ini bersifat deskriptif } \\
& \text { karena menggambarkan kondisi } \\
& \text { pemahaman pendidik terhadap peserta } \\
& \text { didik. Di samping itu penelitian ini } \\
& \text { juga bersifat korelasional karena } \\
& \text { melihat hubungan antara pemahaman } \\
& \text { guru terhadap peserta didik dengan } \\
& \text { implikasi pemahaman tersebut dalam } \\
& \text { proses pembelajaran. }
\end{aligned}
$$

Populasi dalam penelitian ini adalah seluruh guru dan siswa Kelas 1 dan Kelas 2 IPA dan IPS SMA Negeri Kota Padang. Sampel diambil dengan teknik stratified cluster random sampling. Penarikan sampel dalam penelitian ini dilakukan melalui dua tahap. Tahap pertama adalah mengidentifikasi sampel berdasarkan strata sekolah dan dilanjutkan dengan tahap kedua yaitu penentuan sampel berdasarkan kelas, dengan mengikuti langkah yang dikemukakan oleh Cochran (1977).

Sampel penelitian ini adalah SMA Negeri 1 Padang untuk kategori/kelompok tinggi, SMA Negeri 5 Padang untuk kelompok sedang dan SMA Negeri 13 Padang untuk kelompok rendah. Sedangkan guru diambil 8 orang dari masingmasing kelas yang menjadi sampel penelitian yang keseluruhannya berjumlah 72 0rang.

Variabel dalam penelitian ini ada dua yaitu variabel laten pemahaman pendidik tentang peserta didik dengan lima observable variabels yakni: manusia sebagai makhluk yang sempurna, makluk yang tertinggi derajatnya, makhluk yang bertaqwa, 
makhluk menjadi khalifah di bumi dan makhluk pemilik hak asasi manusia (HAM) dan variabel laten implikasi pemahaman guru terhadap proses pembelajaran melalui penerapan high touch dengan enam observable variabels yakni pengakuan, kasih sayang dan kelembutan, penguatan, tindakan tegas yang mendidik, pengarahan dan keteladanan.

Instrumen penelitian ini adalah angket dan dokumentasi. Angket digunakan untuk mengumpulkan data primer berkenaan dengan pemahaman pendidik tentang peserta didik dan implikasinya terhadap proses pembelajaran. Angket penelitian ini disusun dalam bentuk semantik differensial. Sedangkan dokumentasi digunakan untuk memperoleh data skunder berkaitan dengan pelaksanaan proses pembelajaran di sekolah

Pengumpulan data dilakukan langsung oleh peneliti sendiri terhadap seluruh sampel yang telah ditentukan dalam penelitian ini. Data penelitian diperoleh melalui angket yang kemudian dianalisis dengan prosentase, korelasi dan $t$ tes. Untuk mengetahui tingkat pencapaian responden pada masing-masing variabel digunakan +2
SD untuk kategori baik, + 1 SD untuk kategori cukup, mean untuk kategori sedang, - 1 SD untuk kategori kurang dan - 2 SD, untuk kategori cukup.

\section{HASIL DAN PEMBAHASAN}

\section{Gambaran Data Temuan Penelitian}

Profil aplikasi kewibawaan (high touch) berbeda antara apa yang nyatakan oleh guru dengan apa yang dinyatakan oleh siswa. Data hasil temuan penelitian tentang Profil aplikasi pemahaman pendidik tentang peserta didik dalam proses pembelajaran melalui penerapan high touch tergambar pada Grafik sebagai berikut:

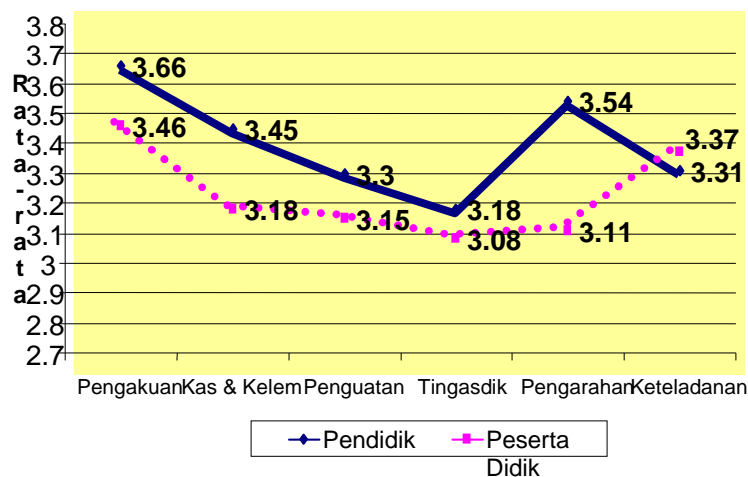

Grafik 1. Profil Aplikasi Kewibawaan dalam Proses Pembelajaran

Berdasarkan data yang tertera dalam Grafik tentang profil aplikasi kewibawaan dalam proses pembelajaran di atas dapat dikemukakan bahwa secara umum 
pendapat guru lebih tinggi dari pendapat siswa. Pendapat peserta didik yang lebih tinggi dari pendapat siswa mencakup lima aspek high touch mencakup: pengakuan, kasih sayang dan kelembutan, penguatan, tindakan tegas yang mendidik serta pengarhan. Sedangkan pada aspek keteladanan ternyata rata-rata skor pendapat siswa lebih tinggi.

Data temuan hasil penelitian sebagaimana terangkum dalam Grafik di atas juga dapat dikemukakan bahwa apabila dilihat dari ketercapaian skor rata-rata (mean) yang diperoleh baik oleh guru maupun oleh siswa terlihat bahwa skor rata-rata pendidik lebih tinggi dari peserta didik. Hal ini dapat dimaknai bahwa pendidik secara umum mengemukakan pendapat yang lebih baik tentang aplikasi kewibawaan dalam proses pembelajaran dari pada apa yang dikatakan siswa. Namun demikian, secara statistik uji beda ini tidak dapat dilakukan (misalnya dengan uji t) karena dikhawatirkan terjadi bias. Hal ini sangat dimungkinkan terjadi karena dalam menilai diri sendiri bisa saja pendidik bersikap kurang objektif.

\section{PEMBAHASAN}

Berdasarkan paparan hasil penelitian di atas secara umum dapat dikemukakan bahwa penerapan kewibawaan masih perlu untuk terus ditingkatkan. Kondisi ini haruslah menjadi perhatian dari semua pihak terkait terutama pihak pimpinan sekolah maupun guru yang bersangkutan untuk dapat mengembangkan lebih lanjut penerapan kewibawaan dalam proses pembelajaran. Hal ini penting mengingat kewibawaan merupakan instrumental dasar bagi guru dalam melaksanakan tugas dan tanggungjawabnya dalam proses pembelajaran.

Tugas dan tanggungjawab guru yang berat menghendaki adanya pemahaman yang baik terhadap tentang kewibawaan dan penerapannya dalam proses pembelajaran. Guru memiliki tanggungjawab dalam mengembangkan potensi peserta didik agar mampu kreatif dan dinamis. Agar potensi tersebut dapat berkembang secara serasi dan maksimal, maka peserta didik harus ditinjau kedudukannya sebagai makhluk yang utuh. Utuh 
sebagai individu (pribadi) dan dalam kaitannya dengan masyarakat.

Tuntutan akan pentingnya penerapan kewibawaan guru terhadap siswa ini juga searah dengan tuntutan yang digariskan oleh kode etik guru yang antara lain menghendaki guru berupaya untuk memperoleh informasi tentang peserta didik sebagai bagan melakukan bimbingan dan pembinaan. Selain itu, guru menciptakan suasana sekolah sebaik-baiknya yang menunjang berhasilnya proses pembelajaran.

Kewibawaan dan penerapannya sangat diperlukan dalam pengembangan proses karena itu merupakan salah satu unsur dari kompetensi paedagogik sebagaimana termuat dalam Stándar pendidikan Nasional. Pemahaman guru tentang kewibawaan dan penerapannya secara positip diharapkan membawa pengaruh/dampak yang besar dalam pengembangan interaksi dalam proses pembelajaran.

Hasil penelitian berkenaan dengan kewibawaan dan penerapannya dalam proses pembelajaran ini juga menghendaki adanya peningkatan pemahaman guru kearah yang lebih baik. Hal ini disebabkan karena tujuan pendidikan itu akan mudah tercapai bila dalam proses pembelajaran, guru menerapkan kewibawaan yang teraktualisasi dalam pelaksanaan tugasnya menjankan proses pembelajaran.

Berdasarkan temuan penelitian di atas, juga dapat dikemukakan bahwa secara umum guru sudah menerapkan kewibawaan walaupun belum atau kurang optimal. Padahal seharusnya guru dapat menerapkan kewibawaan dengan lebih baik dalam proses pembelajaran, karena kewibawaan merupakan alat pendidikan. Kewibawaan merupakan "alat pendidikan" yang diaplikasikan oleh pendidik untuk menjangkau (to touch) kedirian peserta didik dalam hubungan pendidikan. Kewibawaan ini mengarah kepada kondisi high-touch, dalam arti perlakuan pendidik menyentuh secara positif, konstruktif, dan komprehensif aspek-aspek kedirian/kemanusiaan peserta didik. Kewibawaan meliputi: (1) pengakuan, (2) kasih sayang dan kelembutan, (3) penguatan, pengarahan (5) tindakan tegas yang mendidik, dan 6) keteladanan. 
Secara umum guru diharapkan menciptakan kondisi yang baik, yang memungkinkan setiap peserta didik dapat mengembangkan kreativitasnya. Proses pembelajaran pada hakekatnya untuk mengembangkan aktivitas dan creativitas peserta didik, melalui berbagai interaksi dan pengalaman belajar. Namur dalam pelaksanaannya seringkali guru kurang menyadari bahwa masih banyak kegiatan pembelajaran yang dilaksanakan justru menghambat aktivitas dan kreativitas peserta didik.

\section{KESIMPULAN}

$\begin{array}{ccc}\text { Dari } & \text { hasil } & \text { penelitian } \\ \text { diungkapkan } & \text { bahwa } & \text { penerapan }\end{array}$ kewibawaan oleh guru dalam proses pembelajaran masih belum optimal dan perlu untuk terus ditingkatkan ke arah yang lebih baik. Ada penrbedaan pendapat yang cukup signifikan terkait dengan penerapan kewibawaan antara guru dengan siswa terkait dengan penerapan enam observable variabels yakni pengakuan, kasih sayang dan kelembutan, penguatan, tindakan tegas yang mendidik, pengarahan dan keteladanan dalam proses pembelajaran. Secara umum pendapat guru lebih tinggi dibandingkan dengan pendapat siswa.

\section{DAFTAR PUSTAKA}

Ballantine, Jeanne H. (1983). The Sociology of Education, A Systematic Analysis. New Jersey: Prentice-Hall, Inc.

Cohran, William G. (1991). Teknik Penarikan Sampel (penerjemah: Rudiansyah). Jakarta: UI Press

Covey, Stephen R. (1997). Principle Centered Leadership. Jakarta: Bina Rupa Aksara.

G Michael. 1993. The New Meaning of Educational Change. NewYork: Teacher College Press

Ida Umami.. 2004.. Persepsi Peserta didik tentang Konsep dan Kegiatan Bimbingan dan Konseling. Padang Skolar Jurnal Pendidikan Volume 5, No. 2, Desember 2004.: PPS UNP.

Mohd. Ansyar. 1989. Dasar-Dasar Pengembangan Kurikulum. Jakarta: Depdikbud Dirjen Dikti.

Pokja Pengembangan Peta Keilmuan Pendidikan. (2005). Peta Keilmuan Pendidikan. Jakarta: Depdiknas Dirjen Dikti

Prayitno. 2005. Sosok Keilmuan Ilmu Pendidikan. Padang: Fakultas Ilmu Pendidikan UNP. 
Robinson, Philip. (1986). Beberapa

Prespektif Sosiologi

Pendidikan, (penerjemah:

Hasan Basri. Jakarta:

Rajawali

Winarno Surachmad. 2005. Pendidikan

Tanpa Ilmu Pendidikan.

Makalah Disampaikan pada

Seminar Internasional

Pendidikan dan Pertemuan

FIP-JIP. 